\title{
Early life trauma, depression and the glucocorticoid receptor gene - an epigenetic perspective
}

\section{Smart $C^{1}$, Strathdee $G^{2}$, Watson $S^{1,3}$, Murgatroyd $C^{4}$ and McAllister- Williams $\mathrm{RH}^{1,3}$}

1 - Institute of Neuroscience, Newcastle University, UK

2 - Northern Institute for Cancer Research, Newcastle University, UK

3 - Northumberland, Tyne and Wear NHS Foundation Trust, UK

4 - School of Healthcare Science, Manchester Metropolitan University, UK

Corresponding author:

Chris Smart, Institute of Neuroscience, Newcastle University. Academic Psychiatry, Wolfson Research Centre,

Campus for Ageing and Vitality,

Newcastle upon Tyne

NE4 5LP

Tel. +44 (0) 1912081366

Email Chris.Smart@newcastle.ac.uk 


\section{Abstract}

Hopes to identify genetic susceptibility loci accounting for the heritability seen in unipolar depression have not been fully realized. Family history remains the gold standard for both risk stratification and prognosis in complex phenotypes such as depression. Meanwhile, the physiological mechanisms underlying lifeevent triggers for depression remain opaque. Epigenetics, comprising heritable changes in gene expression other than alterations of the nucleotide sequence, may offer a way to deepen our understanding of the aetiology and pathophysiology of unipolar depression and optimise treatments. A heuristic target for exploring the relevance of epigenetic changes in unipolar depression is the hypothalamic-pituitary-adrenal (HPA) axis. The glucocorticoid receptor (GR) gene (NR3C1) has been found to be susceptible to epigenetic modification, specifically DNA methylation, in the context of environmental stress such as early life trauma, which is an established risk for depression later in life. In this review we discuss the progress that has been made by studies that have investigated the relationship between depression, early trauma, the HPA axis and the NR3C1 gene. Difficulties with the design of these studies are also explored. Future efforts will need to comprehensively address epigenetic natural histories at the population, tissue, cell and gene level. The complex interactions between the epigenome, genome and environment, as well as ongoing nosological difficulties, also pose significant challenges. The work that has been done so far is nevertheless encouraging and suggests potential mechanistic and biomarker roles for differential DNA methylation patterns in NR3C1 as well as novel therapeutic targets. 


\section{Introduction}

The scale of present day psychiatric illness is well documented. It is thought to account for nearly $23 \%$ of the disease burden in the UK (Fineberg et al., 2013) and is similarly prominent in worldwide estimates (Murray et al., 2012). One of the largest diagnostic contributors to this burden is unipolar depression, which has a global lifetime prevalence rate of up to $17 \%$ (Flint and Kendler, 2014). Unipolar depression is projected to become the greatest worldwide cause of disability-adjusted life years (DALYs) by the year 2030 (WHO, 2008) and is already associated with significant mortality (Antypa et al., 2013). Thus, there remains an ever-growing need to further our understanding of depression in order to optimise treatments and to alleviate suffering (Collins et al., 2011). Deterministic genetic models for psychiatric illness have proved elusive. Genome-wide association studies (GWAS) have not translated into significant therapeutic gains for disorders such as depression and aetiology from a genetic viewpoint remains opaque (Lewis et al., 2010; Ripke et al., 2013). Possible reasons for this include well-cited nosological difficulties (Casey et al., 2013) incorporating phenomenological, psychopathological and pathophysiological heterogeneity, small effect sizes of individual genes and overestimated heritability (McGuffin et al., 2007; Bohacek and Mansuy, 2013; Uher, 2014). However, a growing body of evidence suggests that epigenetic modification could be a biologically significant factor in depression with potential diagnostic, prognostic and therapeutic uses (Massart et al., 2012; Bohacek et al., 2013; Sun et al., 2013; Bagot et al., 2014).

\section{Heritability of depression}

For many years twin and family studies have highlighted the importance of genetic and environmental factors in the mediation of the vulnerability to depression (Cohen-Woods et al., 2013). In the first meta-analysis of epidemiological studies in depression, Sullivan et al. (2000) compared susceptibility in monozygotic and dizygotic twins. The majority of the variance in liability was attributed to environmental effects specific to the individual (63\%), whilst genetic effects accounted for $37 \%$. Subsequent studies have 
produced similar results (Kendler et al., 2006; Franz et al., 2011; Nivard et al., 2014). This genetic contribution has been examined using linkage and association studies. Gene linkage studies for depression, as well as for other common complex disorders, have been perceived by some to be of only limited success (McGuffin et al., 2007; Nair and Howard, 2013) hence the focus on GWAS. However, even for simple traits, genetic variants identified by GWAS are rarely shown to account for more than $20 \%$ of the heritability (Wood et al., 2014). GWAS has had limited success for depression in finding significant associations with individual genetic variations and there has been no evidence for a recessive model (Cohen-Woods et al., 2013; Chang et al., 2014; Flint and Kendler, 2014; Levinson et al., 2014; Power et al., 2014; Schneider et al., 2014). Even when technical and statistical aspects of GWAS have been taken into account (Gusev et al., 2013) the extent of this disparity between expected and verified genetic components in depression has remained considerable (Castillo-Fernandez et al., 2014) and family history continues to be the most effective method of predicting risk (Maher, 2008). Nevertheless, trying to dovetail epidemiological studies which suggest a considerable genetic component for depression with genetic studies providing a dearth of single nucleotide polymorphism (SNP) associations remains a significant problem.

\section{The HPA axis}

One major endocrinological finding in depression is of a dysregulation of the HPA axis - a pathway important in regulating stress responsivity. Stress has profound effects upon a broad range of physiological systems and is an established trigger for mental illness (Meaney, 2001; Gallagher et al., 2007; Binder et al., 2008; Turner et al., 2010; Klengel et al., 2014). The HPA axis is the foremost neuroendocrine stress response system. Dysregulation of the HPA axis in unipolar depression has been consistently reported since the 1960s (Gibbons, 1964; O'Toole et al., 1997; McAllister-Williams et al., 1998; Holsboer, 2000; Young, 2004; Moser et al., 2007; Pariante and Lightman, 2008). Neuroendocrine studies have shown increased basal and/or activated levels of the HPA axis hormones - corticotropin-releasing hormone $(C R H)$, vasopressin (AVP), adrenocorticotropic hormone (ACTH) and cortisol - in 
plasma, saliva and cerebrospinal fluid (CSF) (Herbert, 2013; Belvederi Murri et al., 2014). Structural changes have also been seen in post-mortem and imaging studies of depressed patients including increased numbers of $\mathrm{CRH}$ secreting neurones in the hypothalamus (Raadsheer et al., 1994) and enlarged pituitary and adrenal gland volumes (Kessing et al., 2011). Meanwhile non-suppression in the dexamethasone/ $\mathrm{CRH}$ test has been associated with inferior treatment response and increased relapse rates in depression (Aubry et al., 2007; Ising et al., 2007; Medina et al., 2013).

The HPA axis is regulated by negative feedback loops incorporating glucocorticoids (GC) and glucocorticoid receptors (GR) (Alt et al., 2010). Thus, studies exploring the mechanism underlying the HPA axis dysregulation that has been documented in depression have focused upon abnormal GR expression and function (Pariante, 2006 and 2009; Cowen, 2009; Anacker et al., 2011). Indeed preclinical and clinical investigations have implicated a significant role for GR abnormalities in depression. Using knock-out mice Boyle et al. (2005) demonstrated that reduced GR function led to disrupted negative feedback inhibition of the HPA axis and depression-like behaviour. Depressed patients have shown reduced peripheral GR levels and increased 24-hour cortisol levels (Yehuda et al., 1993). In line with this, decreased GR mRNA has been demonstrated in post-mortem frontal cortices from depressed patients (Webster et al., 2002), although a more recent study has found increased GR expression in amygdala samples from depressed patients (Wang et al., 2014). These findings have been bolstered by studies implicating improved GR function and increased $G R$ expression in the mechanism of action of certain antidepressants (Pariante and Miller, 2001).

\section{Early life adversity, depression and the HPA axis}

The impact of maternal care and early life adversity has been investigated across several species. Rodents temporarily separated from their mothers in the first few months of life, and those whose mothers provide low levels of licking and grooming (LG) and arched back nursing (ABN) care (Meaney, 2001; Daskalakis et al., 2013), have been shown to exhibit depression-like 
phenotypes (Caldji et al., 2000; Murgatroyd et al., 2009). Early adversity has also been associated with abnormal HPA axis function (Fish et al., 2004; Archer et al., 2014). Liu et al. (1997) demonstrated that high LG-ABN maternal conditions, triggered by brief human handling, were associated with lower levels of plasma adrenocorticotrophic hormone (ACTH) and corticosterone (CS) in response to stress in rat offspring up to 100 days old. These offspring also had greater GC sensitivity, increased levels of hippocampal GR mRNA and lower levels of hypothalamic CRH mRNA. In an associated study, Francis et al. (1999) showed that rat pups cross-fostered from low to high LG-ABN mothers had dampened behavioural responses to stress. More interesting still, these offspring emulated their high LG-ABN foster mothers when caring for their own offspring, while low LG-ABN foster mothers rearing pups from high LG-ABN biological mothers produced offspring with heightened stress responses and low LG-ABN maternal behaviour. Further studies by Murgatroyd and Nephew (2013, and another study currently in submission) have been able to show that exposing rat mothers to chronic stress during lactation leads to reduced levels of maternal care as well as altered neuropeptide regulation and GR expression. Moreover, pups whose mothers were exposed to chronic stress tend themselves to exhibit reduced maternal care in adulthood. These results supported prior studies (Denenberg and Rosenberg, 1967; Danchin et al., 2011) demonstrating that differences in gene expression could be passed from one generation to the next by non-genomic means. Further work has been carried out on epigenetic transgenerational inheritance and it continues to attract much attention (Bohacek et al., 2013; Crean et al., 2014; Babenko et al., 2015).

In humans early life adversity is acknowledged as a significant risk factor for many psychiatric and non-psychiatric illnesses (Rutter, 1985; Meaney, 2001; Maniglio, 2009). Childhood maltreatment - incorporating physical, emotional and sexual abuse and physical and emotional neglect - is a significant source of early life adversity in human populations. In Britain, childhood maltreatment has been estimated to occur in $15-25 \%$ of the population (May-Chahal and Cawson, 2005; Radford et al., 2013) with comparable figures quoted internationally (Ishida et al., 2013; Barbosa et al., 2014; Finkelhor et al., 2014; 
Wildeman et al., 2014). Those who are subjected to childhood maltreatment are thought to be at greater risk of later life depression (Klengel et al., 2014). More specifically, Bifulco et al. (1991) demonstrated an increased risk of depression in women who had been abused as children and other subsequent studies have supported these findings (Kendler et al., 2000; Widom et al., 2007; Alt et al., 2010; Bale et al., 2010; Heim et al., 2010). Such individuals can exhibit persistent neuroendocrine and anatomical changes including: glucocorticoid insensitivity, increased central CRH activity, immune upregulation and reduced hippocampal volume (Heim and Nemeroff, 2001; Heim et al., 2008; Hornung and Heim, 2014). Similar abnormalities have been seen in parentally bereaved children in the form of elevated 24-hour salivary cortisol concentrations (Nicolson, 2004) and elevated cortisol in the dexamethasone/ CRH test (Tyrka et al., 2008). However, stress diathesis remains a complex phenomenon with no absolute demarcation between brief (potentially beneficial) and persistent (potentially damaging) stress. In some instances early adversity has appeared to prime, or 'stress inoculate', the individual to later adversity (Anisman et al., 1998; Carpenter et al., 2007; Watson et al., 2007; Elzinga et al., 2008; Daskalakis et al., 2013). Thus, a relationship clearly exists between early adversity, depression and HPA axis function. The potential for individual genes to exert a mediating role in this relationship is the subject of much current study. One such gene is NR3C1.

\section{The NR3C1 gene}

$N R 3 C 1$ is found on chromosome $5 \mathrm{q} 31-32$ and is over $150 \mathrm{~kb}$ in length (Franke and Foellmer, 1989; Turner et al., 2014). It has 8 translated exons (numbered 2 to 9 ) and is thought to have up to fourteen untranslated alternative first exons (termed $1 \mathrm{a}$ through to $1 \mathrm{j}$, with $1 \mathrm{a}$ and $1 \mathrm{c}$ having six further sub-divisions between them) at its 5' end (Daskalakis and Yehuda, 2014). NR3C1 has a complex promoter structure with one promoter for each of its single alternative first exons (Turner et al., 2010). Alternative first exon transcripts are thought to be important for adjusting GR levels in accordance with cell or tissue type and dynamic environmental conditions (Turner et al., 2006) by differentially regulating translation efficiency and RNA stability (Bockmühl et al., 2011). Transcription factors known to modulate alternative first exon use include 
nerve growth factor inducible protein A (NGFIA) which binds to the exon $1 f$ promoter (Weaver et al., 2004). GR is a ligand-activated transcription factor crucial for the effective functioning of the HPA axis. It translocates to the nucleus after binding GC to regulate the activity of specific target genes, including NR3C1 itself. NR3C1 splice variants and mRNA levels, GR isoforms, co-activators and co-repressors have all been associated with variations in GR activity (Binder, 2009; Turner et al., 2010; Anacker et al., 2011; Szczepankiewicz et al., 2014). Although GR is ubiquitously expressed, its levels are thought to be tightly controlled according to tissue, or even cell, type. Thus, within the brain, levels are higher in areas involved in the stress response such as the paraventricular nucleus, hippocampus and anterior pituitary (Karanth et al., 1997; Uchida et al., 2008; Booij et al., 2013).

\section{Epigenetics}

Epigenetic mechanisms - encompassing DNA methylation, histone modification and non-coding RNAs - act to modulate gene expression (Bird, 2002; Bird, 2007; Weaver et al., 2007; Akbarian and Huang, 2009; Bale et al., 2010; Murgatroyd and Spengler, 2011; Booij et al,, 2013) and arguably have the potential to explain the extent and nature of the risk of depression conferred by the interaction between environmental and genetic factors. Factors determining the extent of the epigenetic modifications include cell type, developmental stage and the nature and severity of environmental stressors.

DNA methylation, the most widely studied epigenetic modification, involves the addition of a methyl group to the 5-carbon position of a cytosine at the 5' end of cytosine-guanine dinucleotides (CpG sites). CpG clusters ('islands') are often present within gene promoter regions in an unmethylated state but when they become methylated the gene with which they are associated is usually silenced. Methylation is thought to exert this silencing effect, in concert with other epigenetic modifications and signalling pathways (Day and Sweatt, 2011; Reul, 2014), by inhibiting the binding of transcription factors to promoter regions. Gene promoter regions, as well as the main gene bodies themselves, have commonly been investigated for differential methylation patterns but more recently methylation within enhancer elements has also been 
recognised (Plank and Dean, 2014). The impact of the location and the extent of methylation required to prevent gene expression remains unclear but, in cancer studies using discordant monozygotic twins, large effects have been seen with absolute increases in methylation of $10 \%$ or less (Galetzka et al., 2012; Heyn et al., 2013). DNA methylation, acknowledged as an important factor in tissue development for many years (Holliday and Pugh, 1975; Riggs, 1975; Razin and Riggs 1980), has emerged as a potential underlying mechanism for changes in GR expression.

Figure 1:

To be inserted here. 


\section{Early life adversity and methylation of NR3C1 in animals}

In 2004 Weaver et al. demonstrated that in rat pups of low LG-ABN mothers $N R 3 C 1$ methylation was increased in hippocampal samples (to rates of 80$100 \%$ ) within the NGFIA binding site of the GR gene's exon 1(7) promoter, the homologue of exon $1 \mathrm{f}$ in humans, and that this was associated with reduced GR expression. Conversely they showed that high LG-ABN maternal care was associated with lower methylation rates $(0-10 \%)$ of the exon $1(7) G R$ promoter in offspring. In agreement with a prior study (Meaney et al., 1996) examining GR expression these differences in methylation rates persisted into the offspring's adulthood. Group differences were eliminated by trichostatin A, a histone deacetylase inhibitor thought to promote demethylation ( $\mathrm{Ou}$ et al., 2007), as well as by cross-fostering. This was the first study in the literature to show a clear link between mothering, long-term changes in DNA methylation patterns and subsequent gene expression. Further studies were conducted with, at times, conflicting results. Daniels et al. (2009), for instance, investigated the impact of separating rat pups from their mothers between postnatal day 2 and 14. Assessment of hippocampi at postnatal day 21 revealed no significant change in methylation within exon 1(7) or the NGFIA binding site between pups separated from their mothers and pups raised normally. Nevertheless, Weaver et al. (2007) demonstrated that high LG-ABN care was associated with demethylation of the 5 ' $\mathrm{CpG}$ dinucleotide in the NGFIA response element specifically. Additionally, the authors showed that increased LG-ABN was correlated with greater NGFIA binding, histone acetylation, GR mRNA levels, hippocampal NGFIA expression and increased amounts of GR protein.

\section{Early life adversity and methylation of NR3C1 in humans}

One of the first studies in humans to examine the relationship between prenatal adversity and NR3C1 methylation was by Oberlander et al. (2008). Children of depressed mothers who had received medication $(n=33)$ were compared with children of untreated depressed mothers $(n=13)$ and controls $(n=36)$. An association was seen between prenatal exposure to third trimester 
maternal depression and increased methylation levels of the NGFIA binding site in exon $1 \mathrm{f}$ of the NR3C1 promoter (deemed CpG sites 1 to 3 ) at birth. CpG site 3, within the NGFIA binding site, was also associated with increased cortisol response at 3 months of age. Antidepressant medication had been associated with increased GR mRNA levels in rodents (Pepin et al., 1992; Pariante and Miller, 2001; Yau et al., 2002) and increased GR density in human peripheral blood cells (Calfa et al., 2002), whilst NR3C1 polymorphisms have been observed to predict antidepressant medication responses (Binder et al., 2004; Spijker and van Rossum, 2012). However, maternal treatment with selective serotonin reuptake inhibitors (SSRIs) in the Oberlander et al. study did not have any observable effect on offspring CpG methylation status. Nevertheless, these findings encouraged other studies (Hompes et al. 2013 for example) to assess the same portion of the exon $1 \mathrm{f}$ promoter and CpG sites. Conradt et al. (2013) reported that newborn offspring exposed to maternal depression in utero had increased methylation at the authors' $\mathrm{CpG}$ site 2 within exon $1 \mathrm{f}$ as well as adverse neurobehavioural outcomes.

Radtke et al. (2011) examined DNA methylation using peripheral blood samples taken from children $(n=24)$ aged up to 19 years old whose mothers had been exposed to violence before, during and after their pregnancy. Increased methylation rates in children were significantly associated with maternal exposure to violence during their pregnancy. Methylation was seen in 7 of the 24 children, in 5 of the $10 \mathrm{CpG}$ sites examined and at rates of up to $10 \%$. Strikingly, there was no association between child NR3C1 methylation and maternal exposure to violence either before or after pregnancy. Maternal $N R 3 C 1$ methylation was not significantly correlated with methylation levels in their children and was unaffected by exposure to violence. This study was the first in humans to show an apparently sustained dysregulation of the HPA axis associated with previous early life psychological stress. However, the lack of data over such a long periods of time, up to 19 years in some instances, and the small sample sizes used meant that innumerable confounders could not be ruled out and the statistical power of the study remained relatively limited. Such site-specific findings, again using the portion of the exon $1 \mathrm{f}$ adopted by Oberlander et al. (2008), were seen in a study by Tyrka et al. (2012) in which 
99 healthy adult subjects showed correlations between NR3C1 methylation at CpG sites 1 and 3 in the exon $1 f$ promoter and previous childhood maltreatment, parental care and parental loss. However, methylation rates at these sites and cortisol response were not correlated and the study did not incorporate gene expression data. Hence, the functional significance of their findings remained debatable.

\section{Depression and methylation of $\mathrm{NR3C1}$}

In a study using buccal DNA from healthy individuals $(n=92)$ Edelman et al. (2012) were able to show that methylation at a single CpG site within a binding site for NGFIA correlated with cortisol response to stress. Furthermore, as a result of epigenetic modifications being chemically stable yet modifiable in accordance with dynamic environmental factors (Meaney and Szyf, 2005; Sweatt, 2009) NR3C1 methylation has been afforded considerable explanatory potential in trying to understand both HPA axis dysregulation and depression (Turner et al., 2010). Inconsistent results from NR3C1 SNP studies in depression (Bouma et al., 2011; Lahti et al., 2011; Lewis et al., 2011; Engineer et al., 2013; Galecka et al., 2013; Koper et al., 2014) have added further impetus to this field of enquiry.

In 2010 Alt et al. conducted a study exploring the possible association between methylation of NR3C1 and depression. The authors assessed $N R 3 C 1$ methylation in post-mortem samples from depressed patients $(n=6)$ in multiple limbic brain regions compared to controls $(n=6)$. Hippocampal exon $1 f$ transcripts were reduced in depressed patients and NGFIA was downregulated within the hippocampus, cingulate gyrus and nucleus accumbens. However, these data demonstrated very low overall levels of methylation in both depressed and control brains, whilst the NR3C1 promoter for exon $1 \mathrm{f}$ was completely unmethylated in all of the samples taken. Thus, the mechanism for this down-regulation in depressed brains appeared to be entirely independent of methylation patterns. However, as the authors themselves acknowledged, this study's power was limited by small sample sizes. More recently Na et al. (2014) compared methylation levels of NR3C1's promoter region in depressed patients $(n=45)$ and controls $(n=72)$. The authors found hypomethylation, rather than hypermethylation, at two CpG 
sites in patients. Neither the Alt et al. (2010) nor the Na et al. (2014) studies were able to provide definitive data regarding HPA axis functioning or childhood trauma. This would appear to be crucial, as illustrated by the following studies incorporating early adversity into models of depression, HPA axis dysfunction and methylation of NR3C1 at different life stages.

\section{Early life adversity, depression and methylation of NR3C1}

McGowan et al. (2009) compared methylation rates in hippocampi of postmortem samples from suicide victims, with and without histories of childhood abuse, and controls ( $n=12$ for each of these three groups). Two thirds of the suicide victims, whether abused or not, were retrospectively diagnosed with mood disorders via psychological autopsies (DSM-III-R). Levels of childhood abuse in suicide victims correlated with higher levels of methylation of the NR3C1 promoter as well as lower NR3C1 mRNA levels, both overall and for the exon $1 f$ splice variant alone. There was no significant difference in methylation rates of the exon 1 f NR3C1 promoter or NR3C1 mRNA levels between non-abused suicide victims and controls. In abused suicide victims CpG site-specific increases in methylation were associated with reduced NGFIA binding and NGFIA-induced transcription. However, this study was limited statistically by the small sample sizes used for each group and the removal of outliers in their final analysis. Also of note was that McGowan et al. (2009) reported exon $1 \mathrm{f}$ levels accounting for up to $60 \%$ of the total amount of expressed NR3C1 promoters. Alt et al. (2010), meanwhile, gave a figure in accordance with previous studies of less than $1 \%$. Such relatively low levels of exon $1 \mathrm{f}$ could detract from its apparent functional importance in comparison to other alternative first exons. Whilst dramatically different expression rates between studies may also reduce the confidence with which results can be generalized.

Perroud et al. (2011) investigated the correlation of the severity of childhood maltreatment with methylation rates in NR3C1 for patients diagnosed with borderline personality disorder (BPD) $(n=101)$, depression $(n=99)$ or depression with co-morbid post-traumatic stress disorder $(n=15)$. A portion of the exon $1 \mathrm{f}$ promoter was analysed with reference to the sequence used by 
Oberlander et al. (2008). They were able to show highly significant associations between methylation of $N R 3 C 1$ and the severity and number of sexual abuse episodes. In a study by Melas et al. (2013) salivary DNA from depressed adults $(n=92)$ were compared with controls $(n=82)$. They examined whether differential methylation rates of $N R 3 C 1$ were associated with various adversities experienced in childhood. Of the $47 \mathrm{CpG}$ sites spanning the exon $1 \mathrm{f}$ promoter that were analysed increased methylation was seen at a single CpG site, near to the NGFIA binding region. This was significantly associated with early parental death. However, this study did not assess childhood abuse, the numbers involved in the adversity sub-groups were not large and only females were included.

Very few studies have identified candidates for human maternal behaviours equivalent to rat LG-ABN. However, in rats the effects of licking and grooming have been shown to be mimicked by stroking pups with a brush (Mulligan et al., 2012). A study by Sharp et al. (2012) demonstrated moderation of the effects of prenatal maternal depression upon emotional and physiological outcomes in human infants through mothers stroking their babies in their first weeks of life. A very recent follow-up study by Murgatroyd et al. (2015) has showed reduced $N R 3 C 1$ methylation associated with maternal stroking in these children, hence bolstering the possible role of epigenetic mechanisms in the long-term effects of early life stress and maternal care. Interestingly, the same study also found interactive effects between prenatal and postnatal maternal depression on methylation of NR3C1's exon 1f. Infants of mothers with low prenatal depression showed increased methylation when exposed to increased postnatal depression - consistent with an interplay between prenatal and postnatal environments. In general terms this is supportive of the foetal origins hypothesis of human disease according to which environmental exposures in utero lead to adaptive modifications in foetal development that act to increase fitness in similar postnatal environments. 
Table 1:

To be inserted here.

\section{Methodological issues and possible future studies}

Whilst these human studies have added overall support to a role for epigenetic modification in the link between early adversity, HPA axis dysregulation and depression vulnerability, attention is increasingly being drawn to inconsistencies in study design that may have prevented causal inferences being made (Daskalakis and Yehuda, 2014; Turecki and Meaney, 2014). In this final section an attempt will be made to give an overview of such inconsistencies in order to offer a potential direction for future studies.

Unlike the majority of animal studies examining NR3C1 methylation, many types of potential stressors, sometimes at different developmental stages, have been used to represent early human adversity. For example, Oberlander et al. (2008) used prenatal exposure to maternal depression whilst Radtke et al. (2011) examined the impact of pre- and perinatal exposure to violence against the mother. Both McGowan et al. (2009) and Perroud et al. (2011) used histories of childhood abuse. Studies examining the impact of early adversity in humans is clearly more limited in design by ethical considerations when compared to animal studies. Given the relatively complex nature of human interactions and stress diathesis there is a need to minimise confounders by standardising the assessment of stressors whenever possible. With regards to using stressors at different developmental stages, the natural history of site-specific methylation, such as the exon $1 \mathrm{f}$ promoter of $N R 3 C 1$, in individual subjects has not been explored. Prenatal stress exposure, as used by Oberlander et al. (2008) and Radtke et al. (2011), has helped to establish the temporal boundaries of what appears to be a developmentally sensitive period for a possible causal chain of adversity, epigenetic modification, HPA dysregulation and subsequent depression. However, substantial differences can be expected in the nature of stresses prenatally compared to postnatally, as well as their developmental consequences, and this again risks introducing many confounders when attempting to interpret data. Future studies need to comprehensively detail adverse events, as is common practice on psychiatric inpatient wards and to a 
lesser degree in the community setting, over extensive periods of time and to combine this with regular assessments of epigenetic modifications.

Human studies have also undertaken analysis in different types of tissue. Peripheral blood has often been used due to its relative acceptability from the patient's perspective and its clinical practicality. Radtke et al. (2011) and Perroud et al. (2011) used DNA extracted from peripheral whole blood whilst Oberlander et al. (2008) investigated mononuclear cells from the cord blood of newborns. Other studies have looked at post-mortem tissue: McGowan et al. (2009) analysed hippocampal specimens whilst Alt et al. (2010) looked at several different limbic regions. Melas et al. (2013), meanwhile, used DNA from saliva. It has already been highlighted that methylation levels may differ between cell types (Glossop et al., 2013; Simar et al., 2014) meaning that comparisons between studies using entirely different tissues could be very challenging. However, evidence has emerged that peripheral blood may be an appropriate tissue to identify biomarkers for depression in the context of genetic studies (Rollins et al. 2010; Hepgul et al., 2013), whilst in a review by Tylee et al. (2013) the methylome was shown to be more highly correlated between blood and brain samples than the transcriptome. Provencal et al. (2012) showed that in rhesus macaques variations in mothering (surrogate versus mother reared) led to differential methylation rates including the A2D681 gene which is the homologue of NR3C1 in humans. A weak but significant correlation was seen in differential methylation between prefrontal cortex samples and T lymphocyte cells. The use of blood samples does have an advantage over the use of post-mortem and placental tissue given that these samples are taken at markedly different physiological states. Saliva samples involve cells from different developmental lineages to both brain and blood tissue and hence the validity of its use is unclear. These various confounders mean that many more studies will be needed before effects directly attributable to early life trauma can be separated from those relating to tissue type. Future investigations also need to involve repeated peripheral samples taken from individuals who have nominated themselves for future brain donation. The measurement of NR3C1 methylation levels across various brain regions in these individuals will allow the consolidation of findings from different tissue types and could lead to effective and clinically 
acceptable therapeutic interventions. Additionally, efforts must be made to isolate specific cell types, primarily those cells found in peripheral blood, in order to establish cell-specific methylation profiles (El-Sayed et al., 2012).

Of particular note in the studies published to date is that there has been considerable heterogeneity in exactly where, and to what extent, within the $N R 3 C 1$ gene and its promoter regions, methylation has been assessed (Labonte et al., 2012; Daskalakis and Yehuda, 2014). Much of the work that has been done has involved a specific location of the NR3C1 gene itself, namely exon $1 \mathrm{f}$ and its promoter region incorporating the binding site for NGFIA. In the first of such studies Oberlander et al. (2008) looked at thirteen CpGs in an area comprising exon 1f, its promoter and a further section downstream of this, using Weaver et al's 2004 study as their main reference. McGowan et al. (2009), meanwhile, looked at 39 CpGs across exon $1 \mathrm{f}$ and its promoter. Perroud et al. (2011) looked at eight CpG sites across the exon if promoter and a further downstream region. Finally, Melas et al. (2012) analysed what are thought to be all of the $47 \mathrm{CpG}$ sites throughout the main body and promoter region of NR3C1's exon 1f. Although some effort has been made to correlate individual $\mathrm{CpG}$ sites across different studies this has not always been possible, and despite occasional agreement in which sites are differentially methylated no conclusive patterns have yet emerged. Hence, there would be benefit in researchers adopting a unified and comprehensive approach to the nucleotide sequence being assessed as well as the individual CpG sites within it. Given the extensive adoption so far of the nucleotide sequence from the Oberlander et al. (2008) study it is recommended that this continues to be used as the minimum and necessary sequence coverage for future NR3C1 methylation studies in depressed patients with a history of early maltreatment.

Investigators have examined different functional correlates for the changes observed in NR3C1 methylation. For example, Oberlander et al. (2008) used salivary cortisol measurements in the morning, following a stressor and in the evening, whereas McGowan et al. (2009) assessed NR3C1 mRNA levels as well as NGFIA binding and NGFIA-induced transcription. Once again this heterogeneity of approaches has potentially impaired efforts to establish causal relationships. Although investigators have amassed a considerable 
amount of evidence for an association between differential methylation and HPA axis function in humans, a causal relationship still needs to be fully established.

Lastly, a recurrent issue in studies examining childhood adversity is that of confounding factors relating to recall bias and the participant's current mental state. Ideally, long term follow-up of children up to and beyond the period of maximum risk of the development of psychiatric illnesses, with objective and detailed documentation of the reported maltreatment, will minimise this complication and simultaneously allow more effective exploration of the consequences of particular maltreatment categories.

\section{Summary}

Studies have continued to emerge that implicate hypermethylation of NR3C1's exon 1f promoter occurring following early trauma with this being associated with HPA axis dysfunction and depression. Results have, however, been inconsistent at times and not without occasional controversy (Dyer, 2014). How much of the observed variation of findings is due to intersubject variability in underlying pathophysiology, as opposed to experimental design, remains to be seen.

There is a need for researchers to adopt more consistent approaches to document the natural history of methylation patterns at individual $\mathrm{CpG}$ sites within NR3C1 after early life adversity. This natural history will need to include other environmental factors such as age and diet (Mathers et al., 2010; Murgatroyd and Spengler, 2011; Suderman et al., 2012; Tyrka et al., 2012; Bakulski and Fallin, 2014). A diet low in folate and high in methionine, for example, has already been associated with increased NR3C1 methylation in mice (Sulistyoningrum et al., 2012). The use of newer, more powerful technologies such as epigenome-wide association studies (EWAS) and single cell analysis are exciting but will bring challenges in terms of consistency, defining cell type, cost and data analysis (Plessy et al., 2012; Callaway, 2014; Robinson et al., 2014).

A significant challenge in the epigenetics of mental illness also continues to be the complex nature of these disorders and their aetiology (Caspi et al., 2003; Eaves et al., 2003; Bowes and Jaffee, 2013; Ehlert, 2013; Brown et al., 
2014; Castillo-Fernandez et al., 2014; Kanherkar et al., 2014). As is the case for most research in psychiatry there is the ever-present issue of difficulties with psychiatric nosology. Most authorities believe that the diagnostic category of "major depressive disorder" contains a heterogeneous collection of disorders with differing underlying pathophysiologies (Schmidt et al., 2011). This will clearly hamper the interpretation of epigenetic data. This may be addressed by exploring the relationship between epigenetic status and endophenotypes such as those defined using the Research Domain Criteria initiative (Insel et al., 2010; Casey et al., 2013).

Studies on depression and NR3C1 methylation are exciting in two main ways. Firstly they suggest a hitherto untapped approach that could help to synthesise a comprehensive and necessarily eclectic theory of depression, aiding our understanding of causal factors and identifying disease biomarkers. Secondly, they have the potential to point towards novel therapeutic targets since epigenetic changes are potentially reversible and therefore amenable to intervention, as has been seen in cancer, cardiovascular disease and neurological disorders (Heerboth et al., 2014; Sandhu et al., 2015). Epigenetics offers a way to optimise the diagnosis, prognosis and treatment of depression. In doing so it could reduce depression's global burden whilst simultaneously providing a truly personalised medicine. 


\section{Conflict of Interests}

The authors declare that there is no conflict of interests regarding the publication of this paper.

This research received no specific grant from any funding agency, commercial or notfor-profit sectors. 


\section{References}

AKBARIAN, S. \& HUANG, H. S. 2009. Epigenetic regulation in human brain-focus on histone lysine methylation. Biol Psychiatry, 65, 198-203.

ALT, S. R., TURNER, J. D., KLOK, M. D., MEIJER, O. C., LAKKE, E. A., DERIJK, R. H. \& MULLER, C. P. 2010. Differential expression of glucocorticoid receptor transcripts in major depressive disorder is not epigenetically programmed.

Psychoneuroendocrinology, 35, 544-56.

ANACKER, C., ZUNSZAIN, P. A., CARVALHO, L. A. \& PARIANTE, C. M. 2011. The glucocorticoid receptor: pivot of depression and of antidepressant treatment? Psychoneuroendocrinology, 36, 415-25.

ANISMAN, H., ZAHARIA, M. D., MEANEY, M. J. \& MERALI, Z. 1998. Do early-life events permanently alter behavioral and hormonal responses to stressors? Int $J$ Dev Neurosci, 16, 149-64.

ANTYPA, N., SERRETTI, A. \& RUJESCU, D. 2013. Serotonergic genes and suicide: a systematic review. Eur Neuropsychopharmacol, 23, 1125-42.

ARCHER, T., OSCAR-BERMAN, M., BLUM, K. \& GOLD, M. 2013. Epigenetic Modulation of Mood Disorders. J Genet Syndr Gene Ther, 4.

AUBRY, J. M., GERVASONI, N., OSIEK, C., PERRET, G., ROSSIER, M. F., BERTSCHY, G. $\&$ BONDOLFI, G. 2007. The DEX/CRH neuroendocrine test and the prediction of depressive relapse in remitted depressed outpatients. J Psychiatr Res, 41, 290-4.

BABENKO, O., KOVALCHUK, I. \& METZ, G. A. 2015. Stress-induced perinatal and transgenerational epigenetic programming of brain development and mental health. Neurosci Biobehav Rev, 48C, 70-91.

BAGOT, R. C., LABONTE, B., PENA, C. J. \& NESTLER, E. J. 2014. Epigenetic signaling in psychiatric disorders: stress and depression. Dialogues Clin Neurosci, 16, 281-95.

BAKULSKI, K. M. \& FALLIN, M. D. 2014. Epigenetic epidemiology: promises for public health research. Environ Mol Mutagen, 55, 171-83.

BALE, T. L., BARAM, T. Z., BROWN, A. S., GOLDSTEIN, J. M., INSEL, T. R., MCCARTHY, M. M., NEMEROFF, C. B., REYES, T. M., SIMERLY, R. B., SUSSER, E. S. \& NESTLER, E. J. 2010. Early life programming and neurodevelopmental disorders. Biol Psychiatry, $68,314-9$.

BARBOSA, L. P., QUEVEDO, L., DA SILVA GDEL, G., JANSEN, K., PINHEIRO, R. T., BRANCO, J., LARA, D., OSES, J. \& DA SILVA, R. A. 2014. Childhood trauma and suicide risk in a sample of young individuals aged 14-35 years in southern Brazil. Child Abuse Negl, 38, 1191-6.

BELVEDERI MURRI, M., PARIANTE, C., MONDELLI, V., MASOTTI, M., ATTI, A. R., MELLACQUA, Z., ANTONIOLI, M., GHIO, L., MENCHETTI, M., ZANETIDOU, S., INNAMORATI, M. \& AMORE, M. 2014. HPA axis and aging in depression: systematic review and meta-analysis. Psychoneuroendocrinology, 41, 46-62.

BIFULCO, A., BROWN, G. W. \& ADLER, Z. 1991. Early sexual abuse and clinical depression in adult life. Br J Psychiatry, 159, 115-22.

BINDER, E. B. 2009. The role of FKBP5, a co-chaperone of the glucocorticoid receptor in the pathogenesis and therapy of affective and anxiety disorders. Psychoneuroendocrinology, 34 Suppl 1, S186-95.

BINDER, E. B., BRADLEY, R. G., LIU, W., EPSTEIN, M. P., DEVEAU, T. C., MERCER, K. B., TANG, Y., GILLESPIE, C. F., HEIM, C. M., NEMEROFF, C. B., SCHWARTZ, A. C., 
CUBELLS, J. F. \& RESSLER, K. J. 2008. Association of FKBP5 polymorphisms and childhood abuse with risk of posttraumatic stress disorder symptoms in adults. JAMA, 299, 1291-305.

BINDER, E. B., SALYAKINA, D., LICHTNER, P., WOCHNIK, G. M., ISING, M., PUTZ, B., PAPIOL, S., SEAMAN, S., LUCAE, S., KOHLI, M. A., NICKEL, T., KUNZEL, H. E., FUCHS, B., MAJER, M., PFENNIG, A., KERN, N., BRUNNER, J., MODELL, S., BAGHAI, T., DEIML, T., ZILL, P., BONDY, B., RUPPRECHT, R., MESSER, T., KOHNLEIN, O., DABITZ, H., BRUCKL, T., MULLER, N., PFISTER, H., LIEB, R., MUELLER, J. C., LOHMUSSAAR, E., STROM, T. M., BETTECKEN, T., MEITINGER, T., UHR, M., REIN, T., HOLSBOER, F. \& MULLER-MYHSOK, B. 2004. Polymorphisms in FKBP5 are associated with increased recurrence of depressive episodes and rapid response to antidepressant treatment. Nat Genet, 36, 1319-25.

BIRD, A. 2002. DNA methylation patterns and epigenetic memory. Genes Dev, 16, 621.

BIRD, A. 2007. Perceptions of epigenetics. Nature, 447, 396-8.

BOCKMUHL, Y., MURGATROYD, C. A., KUCZYNSKA, A., ADCOCK, I. M., ALMEIDA, O. F. \& SPENGLER, D. 2011. Differential regulation and function of 5'-untranslated GRexon 1 transcripts. Mol Endocrinol, 25, 1100-10.

BOHACEK, J., GAPP, K., SAAB, B. J. \& MANSUY, I. M. 2013. Transgenerational epigenetic effects on brain functions. Biol Psychiatry, 73, 313-20.

BOHACEK, J. \& MANSUY, I. M. 2013. Epigenetic inheritance of disease and disease risk. Neuropsychopharmacology, 38, 220-36.

BOOIJ, L., WANG, D., LEVESQUE, M. L., TREMBLAY, R. E. \& SZYF, M. 2013. Looking beyond the DNA sequence: the relevance of DNA methylation processes for the stress-diathesis model of depression. Philos Trans R Soc Lond B Biol Sci, 368, 20120251.

BOUMA, E. M., RIESE, H., NOLTE, I. M., OOSTEROM, E., VERHULST, F. C., ORMEL, J. \& OLDEHINKEL, A. J. 2011. No associations between single nucleotide polymorphisms in corticoid receptor genes and heart rate and cortisol responses to a standardized social stress test in adolescents: the TRAILS study. Behav Genet, 41, 253-61.

BOWES, L. \& JAFFEE, S. R. 2013. Biology, genes, and resilience: toward a multidisciplinary approach. Trauma Violence Abuse, 14, 195-208.

BOYLE, M. P., BREWER, J. A., FUNATSU, M., WOZNIAK, D. F., TSIEN, J. Z., IZUMI, Y. \& MUGLIA, L. J. 2005. Acquired deficit of forebrain glucocorticoid receptor produces depression-like changes in adrenal axis regulation and behavior. Proc Natl Acad Sci U $S$ A, 102, 473-8.

BROWN, G. W., CRAIG, T. K., HARRIS, T. O., HERBERT, J., HODGSON, K., TANSEY, K. E. \& UHER, R. 2014. Functional polymorphism in the brain-derived neurotrophic factor gene interacts with stressful life events but not childhood maltreatment in the etiology of depression. Depress Anxiety, 31, 326-34.

CALDJI, C., DIORIO, J. \& MEANEY, M. J. 2000. Variations in maternal care in infancy regulate the development of stress reactivity. Biol Psychiatry, 48, 1164-74.

CALFA, G., KADEMIAN, S., CESCHIN, D., VEGA, G., RABINOVICH, G. A. \& VOLOSIN, M. 2003. Characterization and functional significance of glucocorticoid receptors in patients with major depression: modulation by antidepressant treatment. Psychoneuroendocrinology, 28, 687-701.

CALLAWAY, E. 2014. Epigenomics starts to make its mark. Nature, 508, 22.

CARPENTER, L. L., CARVALHO, J. P., TYRKA, A. R., WIER, L. M., MELLO, A. F., MELLO, M. F., ANDERSON, G. M., WILKINSON, C. W. \& PRICE, L. H. 2007. Decreased 
adrenocorticotropic hormone and cortisol responses to stress in healthy adults reporting significant childhood maltreatment. Biol Psychiatry, 62, 1080-7.

CASEY, B. J., CRADDOCK, N., CUTHBERT, B. N., HYMAN, S. E., LEE, F. S. \& RESSLER, K. J. 2013. DSM-5 and RDoC: progress in psychiatry research? Nat Rev Neurosci, 14, 810-4.

CASPI, A., SUGDEN, K., MOFFITT, T. E., TAYLOR, A., CRAIG, I. W., HARRINGTON, H., MCCLAY, J., MILL, J., MARTIN, J., BRAITHWAITE, A. \& POULTON, R. 2003. Influence of life stress on depression: moderation by a polymorphism in the 5-HTT gene. Science, 301, 386-9.

CASTILLO-FERNANDEZ, J. E., SPECTOR, T. D. \& BELL, J. T. 2014. Epigenetics of discordant monozygotic twins: implications for disease. Genome Med, 6, 60.

CHANG, S. C., GLYMOUR, M. M., WALTER, S., LIANG, L., KOENEN, K. C., TCHETGEN, E. J., CORNELIS, M. C., KAWACHI, I., RIMM, E. \& KUBZANSKY, L. D. 2014. Genomewide polygenic scoring for a 14-year long-term average depression phenotype. Brain Behav, 4, 298-311.

COHEN-WOODS, S., CRAIG, I. W. \& MCGUFFIN, P. 2013. The current state of play on the molecular genetics of depression. Psychol Med, 43, 673-87.

COLLINS, P. Y., PATEL, V., JOESTL, S. S., MARCH, D., INSEL, T. R., DAAR, A. S., SCIENTIFIC ADVISORY, B., THE EXECUTIVE COMMITTEE OF THE GRAND CHALLENGES ON GLOBAL MENTAL, H., ANDERSON, W., DHANSAY, M. A., PHILLIPS, A., SHURIN, S., WALPORT, M., EWART, W., SAVILL, S. J., BORDIN, I. A., COSTELLO, E. J., DURKIN, M., FAIRBURN, C., GLASS, R. I., HALL, W., HUANG, Y., HYMAN, S. E., JAMISON, K., KAAYA, S., KAPUR, S., KLEINMAN, A., OGUNNIYI, A., OTERO-OJEDA, A., POO, M. M., RAVINDRANATH, V., SAHAKIAN, B. J., SAXENA, S., SINGER, P. A. \& STEIN, D. J. 2011. Grand challenges in global mental health. Nature, 475, 27-30.

CONRADT, E., LESTER, B. M., APPLETON, A. A., ARMSTRONG, D. A. \& MARSIT, C. J. 2013. The roles of DNA methylation of NR3C1 and 11beta-HSD2 and exposure to maternal mood disorder in utero on newborn neurobehavior. Epigenetics, 8, 1321-9.

COWEN, P. J. 2010. Not fade away: the HPA axis and depression. Psychol Med, 40, 14.

CRADDOCK, N. \& MYNORS-WALLIS, L. 2014. Psychiatric diagnosis: impersonal, imperfect and important. Br J Psychiatry, 204, 93-5.

CREAN, A. J., KOPPS, A. M. \& BONDURIANSKY, R. 2014. Revisiting telegony: offspring inherit an acquired characteristic of their mother's previous mate. Ecol Lett, 17, 1545-52.

DANCHIN, E., CHARMANTIER, A., CHAMPAGNE, F. A., MESOUDI, A., PUJOL, B. \& BLANCHET, S. 2011. Beyond DNA: integrating inclusive inheritance into an extended theory of evolution. Nat Rev Genet, 12, 475-86.

DANIELS, W. M., FAIRBAIRN, L. R., VAN TILBURG, G., MCEVOY, C. R., ZIGMOND, M. J., RUSSELL, V. A. \& STEIN, D. J. 2009. Maternal separation alters nerve growth factor and corticosterone levels but not the DNA methylation status of the exon 1(7) glucocorticoid receptor promoter region. Metab Brain Dis, 24, 615-27.

DASKALAKIS, N. P., BAGOT, R. C., PARKER, K. J., VINKERS, C. H. \& DE KLOET, E. R. 2013. The three-hit concept of vulnerability and resilience: toward understanding adaptation to early-life adversity outcome. Psychoneuroendocrinology, 38, 1858-73.

DASKALAKIS, N. P. \& YEHUDA, R. 2014. Site-specific methylation changes in the glucocorticoid receptor exon $1 F$ promoter in relation to life adversity: systematic review of contributing factors. Front Neurosci, 8, 369.

DAY, J. J. \& SWEATT, J. D. 2011. Epigenetic mechanisms in cognition. Neuron, 70, 
813-29.

DENENBERG, V. H. \& ROSENBERG, K. M. 1967. Nongenetic transmission of information. Nature, 216, 549-50.

DYER, O. 2014. Journal retracts article that said childhood trauma could lead to genetic changes. BMJ, 349, g5543.

EAVES, L., SILBERG, J. \& ERKANLI, A. 2003. Resolving multiple epigenetic pathways to adolescent depression. J Child Psychol Psychiatry, 44, 1006-14.

EDELMAN, S., SHALEV, I., UZEFOVSKY, F., ISRAEL, S., KNAFO, A., KREMER, I., MANKUTA, D., KAITZ, M. \& EBSTEIN, R. P. 2012. Epigenetic and genetic factors predict women's salivary cortisol following a threat to the social self. PLoS One, 7, e48597.

EHLERT, U. 2013. Enduring psychobiological effects of childhood adversity. Psychoneuroendocrinology, 38, 1850-7.

EL-SAYED, A. M., HALOOSSIM, M. R., GALEA, S. \& KOENEN, K. C. 2012. Epigenetic modifications associated with suicide and common mood and anxiety disorders: a systematic review of the literature. Biol Mood Anxiety Disord, 2, 10.

ELZINGA, B. M., ROELOFS, K., TOLLENAAR, M. S., BAKVIS, P., VAN PELT, J. \& SPINHOVEN, P. 2008. Diminished cortisol responses to psychosocial stress associated with lifetime adverse events a study among healthy young subjects. Psychoneuroendocrinology, 33, 227-37.

ENGINEER, N., DARWIN, L., NISHIGANDH, D., NGIANGA-BAKWIN, K., SMITH, S. C. \& GRAMMATOPOULOS, D. K. 2013. Association of glucocorticoid and type 1 corticotropin-releasing hormone receptors gene variants and risk for depression during pregnancy and post-partum. J Psychiatr Res, 47, 1166-73.

FINEBERG, N. A., HADDAD, P. M., CARPENTER, L., GANNON, B., SHARPE, R., YOUNG, A. H., JOYCE, E., ROWE, J., WELLSTED, D., NUTT, D. J. \& SAHAKIAN, B. J. 2013. The size, burden and cost of disorders of the brain in the UK. J Psychopharmacol, 27, 76170.

FINKELHOR, D., SHATTUCK, A., TURNER, H. A. \& HAMBY, S. L. 2014. The lifetime prevalence of child sexual abuse and sexual assault assessed in late adolescence. $J$ Adolesc Health, 55, 329-33.

FISH, E. W., SHAHROKH, D., BAGOT, R., CALDJI, C., BREDY, T., SZYF, M. \& MEANEY, M. J. 2004. Epigenetic programming of stress responses through variations in maternal care. Ann N Y Acad Sci, 1036, 167-80.

FLINT, J. \& KENDLER, K. S. 2014. The genetics of major depression. Neuron, 81, 484503.

FRANCIS, D., DIORIO, J., LIU, D. \& MEANEY, M. J. 1999. Nongenomic transmission across generations of maternal behavior and stress responses in the rat. Science, 286, 1155-8.

FRANCKE, U. \& FOELLMER, B. E. 1989. The glucocorticoid receptor gene is in 5q31q32 [corrected]. Genomics, 4, 610-2.

FRANZ, C. E., LYONS, M. J., O'BRIEN, R., PANIZZON, M. S., KIM, K., BHAT, R., GRANT, M. D., TOOMEY, R., EISEN, S., XIAN, H. \& KREMEN, W. S. 2011. A 35-year longitudinal assessment of cognition and midlife depression symptoms: the Vietnam Era Twin Study of Aging. Am J Geriatr Psychiatry, 19, 559-70.

GALECKA, E., SZEMRAJ, J., BIENKIEWICZ, M., MAJSTEREK, I., PRZYBYLOWSKASYGUT, K., GALECKI, P. \& LEWINSKI, A. 2013. Single nucleotide polymorphisms of $\mathrm{NR} 3 \mathrm{Cl}$ gene and recurrent depressive disorder in population of Poland. Mol Biol 
Rep, 40, 1693-9.

GALETZKA, D., HANSMANN, T., EL HAJJ, N., WEIS, E., IRMSCHER, B., LUDWIG, M., SCHNEIDER-RATZKE, B., KOHLSCHMIDT, N., BEYER, V., BARTSCH, O., ZECHNER, U., SPIX, C. \& HAAF, T. 2012. Monozygotic twins discordant for constitutive BRCA1 promoter methylation, childhood cancer and secondary cancer. Epigenetics, 7, 4754.

GALLAGHER, P., WATSON, S., SMITH, M. S., YOUNG, A. H. \& FERRIER, I. N. 2007. Plasma cortisol-dehydroepiandrosterone (DHEA) ratios in schizophrenia and bipolar disorder. Schizophr Res, 90, 258-65.

GIBBONS, J. L. 1964. Cortisol Secretion Rate in Depressive Illness. Arch Gen Psychiatry, 10, 572-5.

GLOSSOP, J. R., NIXON, N. B., EMES, R. D., HAWORTH, K. E., PACKHAM, J. C., DAWES, P. T., FRYER, A. A., MATTEY, D. L. \& FARRELL, W. E. 2013. Epigenome-wide profiling identifies significant differences in DNA methylation between matchedpairs of T- and B-lymphocytes from healthy individuals. Epigenetics, 8, 1188-97.

GUSEV, A., BHATIA, G., ZAITLEN, N., VILHJALMSSON, B. J., DIOGO, D., STAHL, E. A., GREGERSEN, P. K., WORTHINGTON, J., KLARESKOG, L., RAYCHAUDHURI, S., PLENGE, R. M., PASANIUC, B. \& PRICE, A. L. 2013. Quantifying missing heritability at known GWAS loci. PLoS Genet, 9, e1003993.

HEERBOTH, S., LAPINSKA, K., SNYDER, N., LEARY, M., ROLLINSON, S. \& SARKAR, S. 2014. Use of epigenetic drugs in disease: an overview. Genet Epigenet, 6, 9-19.

HEIM, C. \& NEMEROFF, C. B. 2001. The role of childhood trauma in the neurobiology of mood and anxiety disorders: preclinical and clinical studies. Biol Psychiatry, 49, 1023-39.

HEIM, C., NEWPORT, D. J., MLETZKO, T., MILLER, A. H. \& NEMEROFF, C. B. 2008. The link between childhood trauma and depression: insights from HPA axis studies in humans. Psychoneuroendocrinology, 33, 693-710.

HEIM, C., SHUGART, M., CRAIGHEAD, W. E. \& NEMEROFF, C. B. 2010.

Neurobiological and psychiatric consequences of child abuse and neglect. Dev Psychobiol, 52, 671-90.

HEPGUL, N., CATTANEO, A., ZUNSZAIN, P. A. \& PARIANTE, C. M. 2013. Depression pathogenesis and treatment: what can we learn from blood mRNA expression? BMC Med, 11, 28.

HERBERT, J. 2013. Cortisol and depression: three questions for psychiatry. Psychol Med, 43, 449-69.

HEYN, H., CARMONA, F. J., GOMEZ, A., FERREIRA, H. J., BELL, J. T., SAYOLS, S., WARD, K., STEFANSSON, O. A., MORAN, S., SANDOVAL, J., EYFJORD, J. E., SPECTOR, T. D. \& ESTELLER, M. 2013. DNA methylation profiling in breast cancer discordant identical twins identifies DOK7 as novel epigenetic biomarker. Carcinogenesis, 34, 102-8.

HOLLIDAY, R. \& PUGH, J. E. 1975. DNA modification mechanisms and gene activity during development. Science, 187, 226-32.

HOLSBOER, F. 2000. The corticosteroid receptor hypothesis of depression. Neuropsychopharmacology, 23, 477-501.

HOMPES, T., IZZI, B., GELLENS, E., MORREELS, M., FIEUWS, S., PEXSTERS, A., SCHOPS, G., DOM, M., VAN BREE, R., FRESON, K., VERHAEGHE, J., SPITZ, B., DEMYTTENAERE, K., GLOVER, V., VAN DEN BERGH, B., ALLEGAERT, K. \& CLAES, S. 2013. Investigating the influence of maternal cortisol and emotional state during pregnancy on the DNA methylation status of the glucocorticoid receptor gene 
(NR3C1) promoter region in cord blood. J Psychiatr Res, 47, 880-91.

HORNUNG, O. P. \& HEIM, C. M. 2014. Gene-environment interactions and intermediate phenotypes: early trauma and depression. Front Endocrinol (Lausanne), $5,14$.

INSEL, T., CUTHBERT, B., GARVEY, M., HEINSSEN, R., PINE, D. S., QUINN, K., SANISLOW, C. \& WANG, P. 2010. Research domain criteria (RDoC): toward a new classification framework for research on mental disorders. Am J Psychiatry, 167, 74851.

ISHIDA, K., KLEVENS, J., RIVERA-GARCIA, B. \& MIRABAL, B. 2013. Child maltreatment in Puerto Rico: findings from the 2010 National Child Abuse and Neglect Data System. P R Health Sci J, 32, 124-31.

ISING, M., HORSTMANN, S., KLOIBER, S., LUCAE, S., BINDER, E. B., KERN, N., KUNZEL, H. E., PFENNIG, A., UHR, M. \& HOLSBOER, F. 2007. Combined dexamethasone/corticotropin releasing hormone test predicts treatment response in major depression - a potential biomarker? Biol Psychiatry, 62, 47-54.

KANHERKAR, R. R., BHATIA-DEY, N. \& CSOKA, A. B. 2014. Epigenetics across the human lifespan. Front Cell Dev Biol, 2, 49.

KARANTH, S., LINTHORST, A. C., STALLA, G. K., BARDEN, N., HOLSBOER, F. \& REUL, J. M. 1997. Hypothalamic-pituitary-adrenocortical axis changes in a transgenic mouse with impaired glucocorticoid receptor function. Endocrinology, 138, 3476-85.

KENDLER, K. S., BULIK, C. M., SILBERG, J., HETTEMA, J. M., MYERS, J. \& PRESCOTT, C. A. 2000. Childhood sexual abuse and adult psychiatric and substance use disorders in women: an epidemiological and cotwin control analysis. Arch Gen Psychiatry, 57, 953-9.

KENDLER, K. S., GATZ, M., GARDNER, C. O. \& PEDERSEN, N. L. 2006. A Swedish national twin study of lifetime major depression. Am J Psychiatry, 163, 109-14.

KESSING, L. V., WILLER, I. S. \& KNORR, U. 2011. Volume of the adrenal and pituitary glands in depression. Psychoneuroendocrinology, 36, 19-27.

KLENGEL, T., PAPE, J., BINDER, E. B. \& MEHTA, D. 2014. The role of DNA methylation in stress-related psychiatric disorders. Neuropharmacology, 80, 115-32.

KOPER, J. W., VAN ROSSUM, E. F. \& VAN DEN AKKER, E. L. 2014. Glucocorticoid receptor polymorphisms and haplotypes and their expression in health and disease. Steroids, 92, 62-73.

LABONTE, B., YERKO, V., GROSS, J., MECHAWAR, N., MEANEY, M. J., SZYF, M. \& TURECKI, G. 2012. Differential glucocorticoid receptor exon 1(B), 1(C), and 1(H) expression and methylation in suicide completers with a history of childhood abuse. Biol Psychiatry, 72, 41-8.

LAHTI, J., RAIKKONEN, K., BRUCE, S., HEINONEN, K., PESONEN, A. K., RAUTANEN, A., WAHLBECK, K., KERE, J., KAJANTIE, E. \& ERIKSSON, J. G. 2011. Glucocorticoid receptor gene haplotype predicts increased risk of hospital admission for depressive disorders in the Helsinki birth cohort study. J Psychiatr Res, 45, 1160-4.

LEVINSON, D. F., MOSTAFAVI, S., MILANESCHI, Y., RIVERA, M., RIPKE, S., WRAY, N. R. \& SULLIVAN, P. F. 2014. Genetic studies of major depressive disorder: why are there no genome-wide association study findings and what can we do about it? Biol Psychiatry, 76, 510-2.

LEWIS, C. M., NG, M. Y., BUTLER, A. W., COHEN-WOODS, S., UHER, R., PIRLO, K., WEALE, M. E., SCHOSSER, A., PAREDES, U. M., RIVERA, M., CRADDOCK, N., OWEN, M. J., JONES, L., JONES, I., KORSZUN, A., AITCHISON, K. J., SHI, J., QUINN, J. P., MACKENZIE, A., VOLLENWEIDER, P., WAEBER, G., HEATH, S., LATHROP, M., MUGLIA, 
P., BARNES, M. R., WHITTAKER, J. C., TOZZI, F., HOLSBOER, F., PREISIG, M., FARMER, A. E., BREEN, G., CRAIG, I. W. \& MCGUFFIN, P. 2010. Genome-wide association study of major recurrent depression in the U.K. population. Am J Psychiatry, 167, 949-57.

LEWIS, G., COLLISHAW, S., HAROLD, G., RICE, F. \& THAPAR, A. 2012. Maternal depression and child and adolescent depression symptoms: an exploratory test for moderation by CRHR1, FKBP5 and NR3C1 gene variants. Behav Genet, 42, 121-32.

LIU, D., DIORIO, J., TANNENBAUM, B., CALDJI, C., FRANCIS, D., FREEDMAN, A., SHARMA, S., PEARSON, D., PLOTSKY, P. M. \& MEANEY, M. J. 1997. Maternal care, hippocampal glucocorticoid receptors, and hypothalamic-pituitary-adrenal responses to stress. Science, 277, 1659-62.

MAHER, B. 2008. Personal genomes: The case of the missing heritability. Nature, 456, 18-21.

MANIGLIO, R. 2009. The impact of child sexual abuse on health: a systematic review of reviews. Clin Psychol Rev, 29, 647-57.

MASSART, R., MONGEAU, R. \& LANFUMEY, L. 2012. Beyond the monoaminergic hypothesis: neuroplasticity and epigenetic changes in a transgenic mouse model of depression. Philos Trans R Soc Lond B Biol Sci, 367, 2485-94.

MATHERS, J. C., STRATHDEE, G. \& RELTON, C. L. 2010. Induction of epigenetic alterations by dietary and other environmental factors. Adv Genet, 71, 3-39.

MAY-CHAHAL, C. \& CAWSON, P. 2005. Measuring child maltreatment in the United Kingdom: a study of the prevalence of child abuse and neglect. Child Abuse Negl, 29, 969-84.

MCALLISTER-WILLIAMS, R. H., FERRIER, I. N. \& YOUNG, A. H. 1998. Mood and neuropsychological function in depression: the role of corticosteroids and serotonin. Psychol Med, 28, 573-84.

MCGOWAN, P. O., SASAKI, A., D'ALESSIO, A. C., DYMOV, S., LABONTE, B., SZYF, M., TURECKI, G. \& MEANEY, M. J. 2009. Epigenetic regulation of the glucocorticoid receptor in human brain associates with childhood abuse. Nat Neurosci, 12, 342-8.

MCGUFFIN, P., COHEN, S. \& KNIGHT, J. 2007. Homing in on depression genes. Am J Psychiatry, 164, 195-7.

MEANEY, M. J. 2001. Maternal care, gene expression, and the transmission of individual differences in stress reactivity across generations. Annu Rev Neurosci, 24, 1161-92.

MEANEY, M. J., DIORIO, J., FRANCIS, D., WIDDOWSON, J., LAPLANTE, P., CALDJI, C., SHARMA, S., SECKL, J. R. \& PLOTSKY, P. M. 1996. Early environmental regulation of forebrain glucocorticoid receptor gene expression: implications for adrenocortical responses to stress. Dev Neurosci, 18, 49-72.

MEANEY, M. J. \& SZYF, M. 2005. Environmental programming of stress responses through DNA methylation: life at the interface between a dynamic environment and a fixed genome. Dialogues Clin Neurosci, 7, 103-23.

MEDINA, A., SEASHOLTZ, A. F., SHARMA, V., BURKE, S., BUNNEY, W., JR., MYERS, R. M., SCHATZBERG, A., AKIL, H. \& WATSON, S. J. 2013. Glucocorticoid and mineralocorticoid receptor expression in the human hippocampus in major depressive disorder. J Psychiatr Res, 47, 307-14.

MELAS, P. A., WEI, Y., WONG, C. C., SJOHOLM, L. K., ABERG, E., MILL, J., SCHALLING, M., FORSELL, Y. \& LAVEBRATT, C. 2013. Genetic and epigenetic associations of MAOA and NR3C1 with depression and childhood adversities. Int $J$ 
MOSER, D., MOLITOR, A., KUMSTA, R., TATSCHNER, T., RIEDERER, P. \& MEYER, J. 2007. The glucocorticoid receptor gene exon $1-\mathrm{F}$ promoter is not methylated at the NGFI-A binding site in human hippocampus. World J Biol Psychiatry, 8, 262-8.

MULLIGAN, C. J., D'ERRICO, N. C., STEES, J. \& HUGHES, D. A. 2012. Methylation changes at NR3C1 in newborns associate with maternal prenatal stress exposure and newborn birth weight. Epigenetics, 7, 853-7.

MURGATROYD, C., PATCHEV, A. V., WU, Y., MICALE, V., BOCKMUHL, Y., FISCHER, D., HOLSBOER, F., WOTJAK, C. T., ALMEIDA, O. F. \& SPENGLER, D. 2009. Dynamic DNA methylation programs persistent adverse effects of early-life stress. Nat Neurosci, $12,1559-66$.

MURGATROYD, C. \& SPENGLER, D. 2011. Epigenetics of early child development. Front Psychiatry, 2, 16.

MURGATROYD, C., QUINN, J. P., SHARP, H. M., PICKLES, A. \& HILL, J. 2015. Effects of prenatal and postnatal depression, and maternal stroking, at the glucocorticoid receptor gene. Transl Psychiatry, 5 , doi:10.1038/tp.2014.140

MURGATROYD, C. A. \& NEPHEW, B. C. 2013. Effects of early life social stress on maternal behavior and neuroendocrinology. Psychoneuroendocrinology, 38, 219-28.

MURRAY, C. J., VOS, T., LOZANO, R., NAGHAVI, M., FLAXMAN, A. D., MICHAUD, C., EZZATI, M., SHIBUYA, K., SALOMON, J. A., ABDALLA, S., ABOYANS, V., ABRAHAM, J., ACKERMAN, I., AGGARWAL, R., AHN, S. Y., ALI, M. K., ALVARADO, M., ANDERSON, H. R., ANDERSON, L. M., ANDREWS, K. G., ATKINSON, C., BADDOUR, L. M., BAHALIM, A. N., BARKER-COLLO, S., BARRERO, L. H., BARTELS, D. H., BASANEZ, M. G., BAXTER, A., BELL, M. L., BENJAMIN, E. J., BENNETT, D., BERNABE, E., BHALLA, K., BHANDARI, B., BIKBOV, B., BIN ABDULHAK, A., BIRBECK, G., BLACK, J. A.,

BLENCOWE, H., BLORE, J. D., BLYTH, F., BOLLIGER, I., BONAVENTURE, A., BOUFOUS, S., BOURNE, R., BOUSSINESQ, M., BRAITHWAITE, T., BRAYNE, C., BRIDGETT, L., BROOKER, S., BROOKS, P., BRUGHA, T. S., BRYAN-HANCOCK, C., BUCELLO, C., BUCHBINDER, R., BUCKLE, G., BUDKE, C. M., BURCH, M., BURNEY, P., BURSTEIN, R., CALABRIA, B., CAMPBELL, B., CANTER, C. E., CARABIN, H., CARAPETIS, J.,

CARMONA, L., CELLA, C., CHARLSON, F., CHEN, H., CHENG, A. T., CHOU, D., CHUGH, S. S., COFFENG, L. E., COLAN, S. D., COLQUHOUN, S., COLSON, K. E., CONDON, J., CONNOR, M. D., COOPER, L. T., CORRIERE, M., CORTINOVIS, M., DE VACCARO, K. C., COUSER, W., COWIE, B. C., CRIQUI, M. H., CROSS, M., DABHADKAR, K. C., DAHIYA, M., DAHODWALA, N., DAMSERE-DERRY, J., DANAEI, G., DAVIS, A., DE LEO, D., DEGENHARDT, L., DELLAVALLE, R., DELOSSANTOS, A., DENENBERG, J., DERRETT, S., DES JARLAIS, D. C., DHARMARATNE, S. D., et al. 2012. Disability-adjusted life years (DALYs) for 291 diseases and injuries in 21 regions, 1990-2010: a systematic analysis for the Global Burden of Disease Study 2010. Lancet, 380, 2197-223.

NA, K. S., CHANG, H. S., WON, E., HAN, K. M., CHOI, S., TAE, W. S., YOON, H. K., KIM, Y. K., JOE, S. H., JUNG, I. K., LEE, M. S. \& HAM, B. J. 2014. Association between glucocorticoid receptor methylation and hippocampal subfields in major depressive disorder. PLoS One, 9, e85425.

NAIR, A. \& HOWARD, R. 2013. ENCODE and a new landscape for psychiatric genetics. Br J Psychiatry, 203, 84-5.

NEMEROFF, C. B., BISSETTE, G., AKIL, H. \& FINK, M. 1991. Neuropeptide concentrations in the cerebrospinal fluid of depressed patients treated with electroconvulsive therapy. Corticotrophin-releasing factor, beta-endorphin and somatostatin. Br J Psychiatry, 158, 59-63.

NICOLSON, N. A. 2004. Childhood parental loss and cortisol levels in adult men. Psychoneuroendocrinology, 29, 1012-8.

NIVARD, M. G., DOLAN, C. V., KENDLER, K. S., KAN, K. J., WILLEMSEN, G., VAN 
BEIJSTERVELDT, C. E., LINDAUER, R. J., VAN BEEK, J. H., GEELS, L. M., BARTELS, M., MIDDELDORP, C. M. \& BOOMSMA, D. I. 2014. Stability in symptoms of anxiety and depression as a function of genotype and environment: a longitudinal twin study from ages 3 to 63 years. Psychol Med, 1-11.

OBERLANDER, T. F., WEINBERG, J., PAPSDORF, M., GRUNAU, R., MISRI, S. \& DEVLIN, A. M. 2008. Prenatal exposure to maternal depression, neonatal methylation of human glucocorticoid receptor gene (NR3C1) and infant cortisol stress responses. Epigenetics, 3, 97-106.

O'TOOLE, S. M., SEKULA, L. K. \& RUBIN, R. T. 1997. Pituitary-adrenal cortical axis measures as predictors of sustained remission in major depression. Biol Psychiatry, $42,85-9$.

OU, J. N., TORRISANI, J., UNTERBERGER, A., PROVENCAL, N., SHIKIMI, K., KARIMI, M., EKSTROM, T. J. \& SZYF, M. 2007. Histone deacetylase inhibitor Trichostatin A induces global and gene-specific DNA demethylation in human cancer cell lines. Biochem Pharmacol, 73, 1297-307.

PARIANTE, C. M. 2006. The glucocorticoid receptor: part of the solution or part of the problem? J Psychopharmacol, 20, 79-84.

PARIANTE, C. M. 2009. Risk factors for development of depression and psychosis. Glucocorticoid receptors and pituitary implications for treatment with antidepressant and glucocorticoids. Ann N Y Acad Sci, 1179, 144-52.

PARIANTE, C. M. \& LIGHTMAN, S. L. 2008. The HPA axis in major depression: classical theories and new developments. Trends Neurosci, 31, 464-8.

PARIANTE, C. M. \& MILLER, A. H. 2001. Glucocorticoid receptors in major depression: relevance to pathophysiology and treatment. Biol Psychiatry, 49, 391404.

PEPIN, M. C., POTHIER, F. \& BARDEN, N. 1992. Antidepressant drug action in a transgenic mouse model of the endocrine changes seen in depression. $\mathrm{Mol}$ Pharmacol, 42, 991-5.

PLANK, J. L. \& DEAN, A. 2014. Enhancer function: mechanistic and genome-wide insights come together. Mol Cell, 55, 5-14.

PLESSY, C., DESBOIS, L., FUJII, T. \& CARNINCI, P. 2013. Population transcriptomics with single-cell resolution: a new field made possible by microfluidics: a technology for high throughput transcript counting and data-driven definition of cell types. Bioessays, 35, 131-40.

POWER, R. A., KELLER, M. C., RIPKE, S., ABDELLAOUI, A., WRAY, N. R., SULLIVAN, P. F., GROUP, M. P. W. \& BREEN, G. 2014. A recessive genetic model and runs of homozygosity in major depressive disorder. Am J Med Genet B Neuropsychiatr Genet, 165B, 157-66.

PROVENCAL, N., SUDERMAN, M. J., GUILLEMIN, C., MASSART, R., RUGGIERO, A., WANG, D., BENNETT, A. J., PIERRE, P. J., FRIEDMAN, D. P., COTE, S. M., HALLETT, M., TREMBLAY, R. E., SUOMI, S. J. \& SZYF, M. 2012. The signature of maternal rearing in the methylome in rhesus macaque prefrontal cortex and T cells. J Neurosci, 32, 15626-42.

RAADSHEER, F. C., HOOGENDIJK, W. J., STAM, F. C., TILDERS, F. J. \& SWAAB, D. F. 1994. Increased numbers of corticotropin-releasing hormone expressing neurons in the hypothalamic paraventricular nucleus of depressed patients. Neuroendocrinology, $60,436-44$.

RADFORD, L., CORRAL, S., BRADLEY, C. \& FISHER, H. L. 2013. The prevalence and impact of child maltreatment and other types of victimization in the UK: findings from a population survey of caregivers, children and young people and young 
adults. Child Abuse Negl, 37, 801-13.

RADTKE, K. M., RUF, M., GUNTER, H. M., DOHRMANN, K., SCHAUER, M., MEYER, A. \& ELBERT, T. 2011. Transgenerational impact of intimate partner violence on methylation in the promoter of the glucocorticoid receptor. Transl Psychiatry, 1, e21.

RAZIN, A. \& RIGGS, A. D. 1980. DNA methylation and gene function. Science, 210, 604-10.

REUL, J. M. 2014. Making memories of stressful events: a journey along epigenetic, gene transcription, and signaling pathways. Front Psychiatry, 5, 5.

RIGGS, A. D. 1975. X inactivation, differentiation, and DNA methylation. Cytogenet Cell Genet, 14, 9-25.

RIPKE, S., WRAY, N. R., LEWIS, C. M., HAMILTON, S. P., WEISSMAN, M. M., BREEN, G., BYRNE, E. M., BLACKWOOD, D. H., BOOMSMA, D. I., CICHON, S., HEATH, A. C., HOLSBOER, F., LUCAE, S., MADDEN, P. A., MARTIN, N. G., MCGUFFIN, P., MUGLIA, P., NOETHEN, M. M., PENNINX, B. P., PERGADIA, M. L., POTASH, J. B., RIETSCHEL, M., LIN, D., MULLER-MYHSOK, B., SHI, J., STEINBERG, S., GRABE, H. J., LICHTENSTEIN, P., MAGNUSSON, P., PERLIS, R. H., PREISIG, M., SMOLLER, J. W., STEFANSSON, K., UHER, R., KUTALIK, Z., TANSEY, K. E., TEUMER, A., VIKTORIN, A., BARNES, M. R., BETTECKEN, T., BINDER, E. B., BREUER, R., CASTRO, V. M., CHURCHILL, S. E., CORYELL, W. H., CRADDOCK, N., CRAIG, I. W., CZAMARA, D., DE GEUS, E. J., DEGENHARDT, F., FARMER, A. E., FAVA, M., FRANK, J., GAINER, V. S., GALLAGHER, P. J., GORDON, S. D., GORYACHEV, S., GROSS, M., GUIPPONI, M., HENDERS, A. K., HERMS, S., HICKIE, I. B., HOEFELS, S., HOOGENDIJK, W., HOTTENGA, J. J.,

IOSIFESCU, D. V., ISING, M., JONES, I., JONES, L., JUNG-YING, T., KNOWLES, J. A., KOHANE, I. S., KOHLI, M. A., KORSZUN, A., LANDEN, M., LAWSON, W. B., LEWIS, G., MACINTYRE, D., MAIER, W., MATTHEISEN, M., MCGRATH, P. J., MCINTOSH, A., MCLEAN, A., MIDDELDORP, C. M., MIDDLETON, L., MONTGOMERY, G. M., MURPHY, S. N., NAUCK, M., NOLEN, W. A., NYHOLT, D. R., O'DONOVAN, M., OSKARSSON, H., PEDERSEN, N., SCHEFTNER, W. A., SCHULZ, A., SCHULZE, T. G., SHYN, S. I., SIGURDSSON, E., SLAGER, S. L., et al. MAJOR DEPRESSIVE DISORDER WORKING GROUP OF THE PSYCHIATRIC GWAS CONSORTIUM. 2013. A mega-analysis of genome-wide association studies for major depressive disorder. Mol Psychiatry, 18, 497-511.

ROBINSON, M. D., KAHRAMAN, A., LAW, C. W., LINDSAY, H., NOWICKA, M., WEBER, L. M. \& ZHOU, X. 2014. Statistical methods for detecting differentially methylated loci and regions. Front Genet, 5, 324.

ROLLINS, B., MARTIN, M. V., MORGAN, L. \& VAWTER, M. P. 2010. Analysis of whole genome biomarker expression in blood and brain. Am J Med Genet B Neuropsychiatr Genet, 153B, 919-36.

RUTTER, M. 1985. Resilience in the face of adversity. Protective factors and resistance to psychiatric disorder. Br J Psychiatry, 147, 598-611.

SANDHU, R., ROLL, J. D., RIVENBARK, A. G. \& COLEMAN, W. B. 2015. Dysregulation of the Epigenome in Human Breast Cancer: Contributions of Gene-Specific DNA Hypermethylation to Breast Cancer Pathobiology and Targeting the Breast Cancer Methylome for Improved Therapy. Am J Pathol, 185, 282-292.

SCHMIDT, H. D., SHELTON, R. C. \& DUMAN, R. S. 2011. Functional biomarkers of depression: diagnosis, treatment, and pathophysiology. Neuropsychopharmacology, 36, 2375-94.

SCHNEIDER, M., ENGEL, A., FASCHING, P. A., HABERLE, L., BINDER, E. B., VOIGT, F., GRIMM, J., FASCHINGBAUER, F., EICHLER, A., DAMMER, U., REBHAN, D., AMANN, M., RAABE, E., GOECKE, T. W., QUAST, C., BECKMANN, M. W., KORNHUBER, J., SEIFERT, A. \& BURGHAUS, S. 2014. Genetic variants in the genes of the stress hormone signalling pathway and depressive symptoms during and after pregnancy. Biomed Res Int, 2014, 469278. 
SHARP, H., PICKLES, A., MEANEY, M., MARSHALL, K., TIBU, F. \& HILL, J. 2012. Frequency of infant stroking reported by mothers moderates the effect of prenatal depression on infant behavioural and physiological outcomes. PLoS One, 7, e45446.

SIMAR, D., VERSTEYHE, S., DONKIN, I., LIU, J., HESSON, L., NYLANDER, V., FOSSUM, A. \& BARRES, R. 2014. DNA methylation is altered in B and NK lymphocytes in obese and type 2 diabetic human. Metabolism, 63, 1188-97.

SPIJKER, A. T. \& VAN ROSSUM, E. F. 2012. Glucocorticoid sensitivity in mood disorders. Neuroendocrinology, 95, 179-86.

SUDERMAN, M., MCGOWAN, P. O., SASAKI, A., HUANG, T. C., HALLETT, M. T., MEANEY, M. J., TURECKI, G. \& SZYF, M. 2012. Conserved epigenetic sensitivity to early life experience in the rat and human hippocampus. Proc Natl Acad Sci U $S A$, 109 Suppl 2, 17266-72.

SULISTYONINGRUM, D. C., SINGH, R. \& DEVLIN, A. M. 2012. Epigenetic regulation of glucocorticoid receptor expression in aorta from mice with hyperhomocysteinemia. Epigenetics, 7, 514-21.

SULLIVAN, P. F., NEALE, M. C. \& KENDLER, K. S. 2000. Genetic epidemiology of major depression: review and meta-analysis. Am J Psychiatry, 157, 1552-62.

SUN, H., KENNEDY, P. J. \& NESTLER, E. J. 2013. Epigenetics of the depressed brain: role of histone acetylation and methylation. Neuropsychopharmacology, 38, 124-37.

SWEATT, J. D. 2009. Experience-dependent epigenetic modifications in the central nervous system. Biol Psychiatry, 65, 191-7.

SZCZEPANKIEWICZ, A., LESZCZYNSKA-RODZIEWICZ, A., PAWLAK, J., NAROZNA, B., RAJEWSKA-RAGER, A., WILKOSC, M., ZAREMBA, D., MACIUKIEWICZ, M. \& TWAROWSKA-HAUSER, J. 2014. FKBP5 polymorphism is associated with major depression but not with bipolar disorder. J Affect Disord, 164, 33-7.

TURECKI, G. \& MEANEY, M. J. 2014. Effects of the Social Environment and Stress on Glucocorticoid Receptor Gene Methylation: A Systematic Review. Biol Psychiatry.

TURNER, J. D., ALT, S. R., CAO, L., VERNOCCHI, S., TRIFONOVA, S., BATTELLO, N. \& MULLER, C. P. 2010. Transcriptional control of the glucocorticoid receptor: CpG islands, epigenetics and more. Biochem Pharmacol, 80, 1860-8.

TURNER, J. D. \& MULLER, C. P. 2005. Structure of the glucocorticoid receptor (NR3C1) gene 5 ' untranslated region: identification, and tissue distribution of multiple new human exon 1. J Mol Endocrinol, 35, 283-92.

TURNER, J. D., SCHOTE, A. B., MACEDO, J. A., PELASCINI, L. P. \& MULLER, C. P. 2006. Tissue specific glucocorticoid receptor expression, a role for alternative first exon usage? Biochem Pharmacol, 72, 1529-37.

TURNER, J. D., VERNOCCHI, S., SCHMITZ, S. \& MULLER, C. P. 2014. Role of the 5'untranslated regions in post-transcriptional regulation of the human glucocorticoid receptor. Biochim Biophys Acta, 1839, 1051-61.

TYLEE, D. S., KAWAGUCHI, D. M. \& GLATT, S. J. 2013. On the outside, looking in: a review and evaluation of the comparability of blood and brain "-omes". Am J Med Genet B Neuropsychiatr Genet, 162B, 595-603.

TYRKA, A. R., PRICE, L. H., MARSIT, C., WALTERS, O. C. \& CARPENTER, L. L. 2012. Childhood adversity and epigenetic modulation of the leukocyte glucocorticoid receptor: preliminary findings in healthy adults. PLoS One, 7, e30148.

TYRKA, A. R., WIER, L., PRICE, L. H., ROSS, N., ANDERSON, G. M., WILKINSON, C. W. \& CARPENTER, L. L. 2008. Childhood parental loss and adult hypothalamic- 
pituitary-adrenal function. Biol Psychiatry, 63, 1147-54.

UCHIDA, S., NISHIDA, A., HARA, K., KAMEMOTO, T., SUETSUGI, M., FUJIMOTO, M., WATANUKI, T., WAKABAYASHI, Y., OTSUKI, K., MCEWEN, B. S. \& WATANABE, Y. 2008. Characterization of the vulnerability to repeated stress in Fischer 344 rats: possible involvement of microRNA-mediated down-regulation of the glucocorticoid receptor. Eur J Neurosci, 27, 2250-61.

UHER, R. 2014. Gene-environment interactions in common mental disorders: an update and strategy for a genome-wide search. Soc Psychiatry Psychiatr Epidemiol, 49, 3-14.

WANG, Q., VERWEIJ, E. W., KRUGERS, H. J., JOELS, M., SWAAB, D. F. \& LUCASSEN, P. J. 2014. Distribution of the glucocorticoid receptor in the human amygdala; changes in mood disorder patients. Brain Struct Funct, 219, 1615-26.

WATSON, S., OWEN, B. M., GALLAGHER, P., HEARN, A. J., YOUNG, A. H. \& FERRIER, I. N. 2007. Family history, early adversity and the hypothalamic-pituitary-adrenal (HPA) axis: Mediation of the vulnerability to mood disorders. Neuropsychiatr Dis Treat, 3, 647-53.

WEAVER, I. C., CERVONI, N., CHAMPAGNE, F. A., D'ALESSIO, A. C., SHARMA, S., SECKL, J. R., DYMOV, S., SZYF, M. \& MEANEY, M. J. 2004. Epigenetic programming by maternal behavior. Nat Neurosci, 7, 847-54.

WEAVER, I. C., D'ALESSIO, A. C., BROWN, S. E., HELLSTROM, I. C., DYMOV, S., SHARMA, S., SZYF, M. \& MEANEY, M. J. 2007. The transcription factor nerve growth factor-inducible protein a mediates epigenetic programming: altering epigenetic marks by immediate-early genes. J Neurosci, 27, 1756-68.

WEBSTER, M. J., KNABLE, M. B., O'GRADY, J., ORTHMANN, J. \& WEICKERT, C. S. 2002. Regional specificity of brain glucocorticoid receptor mRNA alterations in subjects with schizophrenia and mood disorders. Mol Psychiatry, 7, 985-94, 924.

WIDOM, C. S., DUMONT, K. \& CZAJA, S. J. 2007. A prospective investigation of major depressive disorder and comorbidity in abused and neglected children grown up. Arch Gen Psychiatry, 64, 49-56.

WILDEMAN, C., EMANUEL, N., LEVENTHAL, J. M., PUTNAM-HORNSTEIN, E., WALDFOGEL, J. \& LEE, H. 2014. The prevalence of confirmed maltreatment among US children, 2004 to 2011. JAMA Pediatr, 168, 706-13.

WOOD, A. R., ESKO, T., YANG, J., VEDANTAM, S., PERS, T. H., GUSTAFSSON, S., CHU, A. Y., ESTRADA, K., LUAN, J., KUTALIK, Z., AMIN, N., BUCHKOVICH, M. L., CROTEAUCHONKA, D. C., DAY, F. R., DUAN, Y., FALL, T., FEHRMANN, R., FERREIRA, T., JACKSON, A. U., KARJALAINEN, J., LO, K. S., LOCKE, A. E., MAGI, R., MIHAILOV, E., PORCU, E., RANDALL, J. C., SCHERAG, A., VINKHUYZEN, A. A., WESTRA, H. J., WINKLER, T. W., WORKALEMAHU, T., ZHAO, J. H., ABSHER, D., ALBRECHT, E., ANDERSON, D., BARON, J., BEEKMAN, M., DEMIRKAN, A., EHRET, G. B., FEENSTRA, B., FEITOSA, M. F., FISCHER, K., FRASER, R. M., GOEL, A., GONG, J., JUSTICE, A. E., KANONI, S., KLEBER, M. E., KRISTIANSSON, K., LIM, U., LOTAY, V., LUI, J. C., MANGINO, M., MATEO LEACH, I., MEDINA-GOMEZ, C., NALLS, M. A., NYHOLT, D. R., PALMER, C. D., PASKO, D., PECHLIVANIS, S., PROKOPENKO, I., RIED, J. S., RIPKE, S., SHUNGIN, D., STANCAKOVA, A., STRAWBRIDGE, R. J., SUNG, Y. J., TANAKA, T., TEUMER, A., TROMPET, S., VAN DER LAAN, S. W., VAN SETTEN, J., VAN VLIETOSTAPTCHOUK, J. V., WANG, Z., YENGO, L., ZHANG, W., AFZAL, U., ARNLOV, J., ARSCOTT, G. M., BANDINELLI, S., BARRETT, A., BELLIS, C., BENNETT, A. J., BERNE, C., BLUHER, M., BOLTON, J. L., BOTTCHER, Y., BOYD, H. A., BRUINENBERG, M., BUCKLEY, B. M., BUYSKE, S., CASPERSEN, I. H., CHINES, P. S., CLARKE, R., CLAUDIBOEHM, S., COOPER, M., DAW, E. W., DE JONG, P. A., DEELEN, J., DELGADO, G., et al. 2014. Defining the role of common variation in the genomic and biological architecture of adult human height. Nat Genet, 46, 1173-86.

WORLD HEALTH ORGANISATION. 2008. Global Burden of Disease Report 
http://www.who.int/healthinfo/global_burden_disease/estimates_country/en/index.html

YAU, J. L., HIBBERD, C., NOBLE, J. \& SECKL, J. R. 2002. The effect of chronic fluoxetine treatment on brain corticosteroid receptor mRNA expression and spatial memory in young and aged rats. Brain Res Mol Brain Res, 106, 117-23.

YEHUDA, R., BOISONEAU, D., MASON, J. W. \& GILLER, E. L. 1993. Glucocorticoid receptor number and cortisol excretion in mood, anxiety, and psychotic disorders. Biol Psychiatry, 34, 18-25.

YOUNG, A. H. 2004. Cortisol in mood disorders. Stress, 7, 205-8. 